\title{
DISTINCTIVE FEATURES OF CLASSIFICATION OF FACTORS DETERMINING THE ECONOMIC BEHAVIOR OF ECONOMIC ENTITIES PREDOMINANTLY RURAL AREAS FROM THE STANDPOINT OF THE THEORY OF LONG WAVES
}

\section{Roman Kapinos ${ }^{9}$, Alina Dobrunova ${ }^{10}$, Olga Akupiyan ${ }^{11}$, Dmitriy Kravchenko ${ }^{12}$}

\begin{abstract}
The article presents the results of socio-economic research of factors affecting the economic behavior of economic entities of rural areas, performed on the basis of the theory of super long economic waves. During a large-scale sociological survey in three main age categories of the population, which is represented by different regions, it was revealed, that economic behavior is influenced by the following groups of factors depending on their degree of importance: the moral-religious, political, social, cultural, economic. The results of the research should be taken into account while creating and implementing the macroeconomic policy, including agricultural policy of the state, as well as in the microeconomic policies of firms.
\end{abstract}

KEY WORDS: factors of economic activity, classification of factors, long economic wave, the theory of super-long waves, economic entities of rural areas

JEL:R10

UDC: 330.34 .01

332.122:338.43

COBISS.SR-ID 272174860

\footnotetext{
${ }^{9}$ Department of economic theory and Economics of agroindustrial complex of Belgorod state agrarian University named after $V$. Ya. Gorin

${ }^{10}$ Department of Belgorod state agrarian University named after V. Ya. Gorin

${ }^{11}$ Department of economic theory and Economics of agroindustrial complex of Belgorod state agrarian University named after V. Ya. Gorin

${ }^{12}$ Department of economic theory and Economics of agroindustrial complex of Belgorod state agrarian University named after $V$. Ya. Gorin
} 


\section{INTRODUCTION}

Every few generations (on average every 100-200 years) the society forms a new outlook, a new view of the world, which can be seen in a fundamental change of moral and religious ideas, and this ideological turning point, which approves new principles of life inevitably affects all municipal, and above all, economic relations between people - nothing affects the economic system more than a complete change of people's psychology. Long waves obey social, political and cultural factors, but in their turn these factors are influenced by the factors which determine the psychology of people - a religious factor, that is their moral principles, their beliefs.

\section{LATEST RESEARCH AND PUBLICATIONS ANALYSIS}

K. Marx (Tugan-Baranovskij, 1903; Marx, 1934; Lapin, 1976; Ballaev, 2004; Marx, 2010; Shumpeter, 2011) and his disciples were among the pioneers of the theory of super-long waves. He was developing the doctrine of «economic structure», but very narrowly, considering that economy is greatly influencedby a social factor - the class structure and the class struggle. Later, the beginning of the theory of super-long waves was offered by M. Weber (arguing that Protestantism was the main origin of capitalism factor) $(1990 ; 1994 ; 2006 ; 2010)$ and W. Sombart (describing the same factor as Judaism) $(1912 ; 2004 ; 2005)$ - ignoring that the most important factor in the emergence of the international market can be called Islam as well (Metekov, Spain and Portugal Muslims as a rejected class that was extremely active for hundreds of years dealing with all kinds of business).

\section{KEY RESULTS OF THE RESEARCH}

In order to identify the degree of influence of various factors on the economic behavior of people, the author of the article conducted a number of interviews in April-June 2016 and February-March 2018, which were attended by a total of 2 thousand people in 3 different age categories from 20 regions, mainly rural areas of Russia and Ukraine, as well as from neighboring countries. In the course of anonymous surveys the questions which define the influence of various categories of reasons influencing both the awareness and behavior of business entities were asked. The research determined a high degree of moral-religious ideology influence on the economic activity of people.

In the course of the survey the following issues were touched upon:

1 . What is the main reason of your desire to be a rich man?

1) the desire to take the rightful place in the society (a social cause);

2) a dream to help the others (a moral-religious reason);

3) the need for decent clothes (a social cause);

4) the need for a comfortable accommodation and a good car (an economic reason);

5) the possibility to become a sponsor of the party (a political cause);

6) the opportunity to become a sponsor of the orphanage or welfare fund (a moral-religious reason);

7) the opportunity to open their own theatre or a school (a cultural reason).

2. What can help you to become a very rich man? 
1) the luck from heaven (a moral-religious reason);

2) state authority - the skilful management of the country (a political cause);

3) higher education - and continuous self-studying (a cultural reason);

4) a large number of books which were read (a cultural reason).

3. How do you think the famous rich people have succeeded in life due to:

1) hard and honest work (a moral-religious reason); large inheritance (a social cause);

2) studying a lot (a cultural reason);

3) having a lot of friends (a social reason);

4) the protection of a deputy, a mayor or a minister (a political reason).

All the questions in the course of the survey, dealing with one or another factor of influence (political, cultural, moral, religious, social and economic) were put in the questionnaire at random order, which excluded the possibility of any subconscious infusion.

The first category included children from 5 to 18. According to their answers to the first question in the first place among the factors that affect their economic behavior there is a social reason, in the second place there is a moral-religious one. Among the answers to the second question a cultural reason is in the first place, a political reason is in the second and a moralreligious is in the third place. In the answers to the third question a moral-religious factor was in the first place, a cultural factor was in the second place.

The second category involved young people from 18 to 30 . Their answers to the first question have shown that the first place among the factors that affect their economic behavior is taken by a social reason, the second is taken by a moral-religious one. Answers to the second question showed the following results: the first place - the culture, the second - the morality, religion and politics. Answers to the third question revealed that the first place for this category of the population is taken by a political factor, the second place - by a moral-religious one, and the third place is taken by a cultural factor.

The third category of respondents are mature people aged 30-50, the most economically active of the three categories. Analysis of the responses to the first question has shown that a moral-religious factor is in the first place among the factors of influence on economic behavior for this category (as well as social and economic factors). Answers to the second question once again put a moral-religious factor to the first place. Answers to the third question put a moralreligious factor to the first place (as well as a political factor).

Analysis of the data shows that moral-religious, political and cultural factors of people's economic behavior are steadily between the first and second place, social factors usually hold the first place. At the same time, there are political, moral- religious and social factors at first places in all three age groups.

However, the most frequently mentioned places are distributed clearly in the following way:

1. Moral-religious factors (9 out of 9: in all age categories, while answering all questions).

2. Political (in 4 cases out of 9).

3. Social (in 3 cases out of 9 ).

4. Cultural (in 3 cases out of 9). 


\section{Economical (1 case of 9).}

Consequently, the factors of the long economic wave graphically can be presented like this (Figure 1):

Figure 1: Gradation of factors of the long economic waves

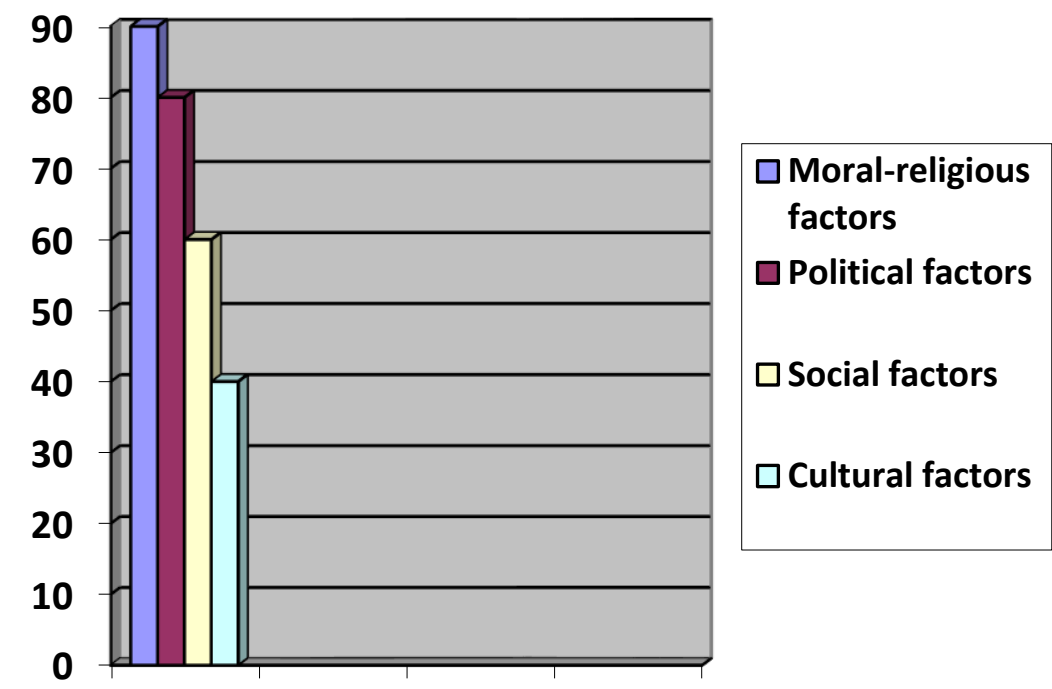

The basic postulate put forward the theory of super-long economic waves is the following: every 2-3 human generations ( 1 every 100-200 years) the society radically changes the underlying moral and religious principles of his philosophy, is a genuine religious revolution, when the demolition of the old and the emergence of a new folk psychology - that leads to an economic revolution, a complete change in the economic conditions of the hostel people, and further, damped waves, there are social, political, and cultural reform, in General, changing the entire public and private lives of people.

Table 1.Examples of long waves in the history of social and agrarian economy

\begin{tabular}{|l|l|l|l|}
\hline Years & Moral-religious revolutions & Years & Economic leap (wave) \\
\hline 4th century & $\begin{array}{l}\text { Christian revolution which } \\
\text { approved Christianity as the state } \\
\text { religion of Rome and } \\
\text { Constantinople (In 324 } \\
\text { Constantine I. officially declared } \\
\text { Christianity the state religion) }\end{array}$ & th century & $\begin{array}{l}\text { The destruction of the slave } \\
\text { system, the change to the } \\
\text { feudal landlord economy (332 } \\
\text { y. Constantine I passes a law } \\
\text { which assigns slaves to estates) }\end{array}$ \\
\hline 17 th century & $\begin{array}{l}\text { The Protestant Revolution (16- } \\
17 \text { th centuries - the } \\
\text { Reformation) }\end{array}$ & $\begin{array}{l}\text { Formation of capitalist relations } \\
\text { (the middle of 15 - 18th } \\
\text { centuries } \\
\text { accumulation of capital in } \\
\text { Europe) }\end{array}$ \\
\hline
\end{tabular}




\begin{tabular}{|l|l|l|l|}
\hline 18th century & $\begin{array}{l}\text { Anglo-French anticlergy } \\
\text { Enlightenment (the end of 17- } \\
\text { the beginning of 19th century). }\end{array}$ & $\begin{array}{l}\text { The Industrial Revolution in } \\
\text { England, Western Europe and } \\
\text { the United States (18-19th } \\
\text { centuries.) }\end{array}$ \\
\hline 20th century & $\begin{array}{l}\text { The Communist Revolution of } \\
1917 .\end{array}$ & $\begin{array}{l}\text { Formation of the new global } \\
\text { economy }\end{array}$ \\
\hline 21 st century & $\begin{array}{l}\text { Islamic and Orthodox revolution of } \\
\text { the 21st century. }\end{array}$ & $\begin{array}{l}\text { Ast century new, possibly theocratic, } \\
\text { economy }\end{array}$ \\
\hline
\end{tabular}

Source: compiled by the author.

The results of extended public opinion poll were cross-checked on the basis of a narrower special survey conducted during January-July 2016 among 2 thousand respondents. The respondents were asked one question: if there is sufficient surplus (personal income), would you agree to spend it on the three objectives proposed by the "father of economics" Ksenofont (1993):

1. Support for the homeland (a moral-religious goal).

2. Help for your friends (a moral goal).

3. Worship God/gods (a religious goal).

Up to $50 \%$ supported all three goals, up to $80 \%$ supported one of the proposals and up to $100 \%$ - at least one of the three. The results of this special poll again confirmed the high degree of moral-religious factors influence on the economic behavior of economic subjects even under the world domination of market relations and the capitalist economy (Zadorozhny j, 2012; Kapinos, 2006, 2014, 2015; Yagutkin, Yagutkina, 2017; Kitaev, 2017).

Societies which were based on religious relations, and the superstructure was based on economic relations, in most cases, achieved striking economic success. Table 2. gives some typical examples.

Table 2: The ratio of the degree of the religious ideology development of the national economy, including agriculture, and the level of its productivity

\begin{tabular}{|c|c|}
\hline $\begin{array}{l}\text { The level of religious } \\
\text { consciousness of the people }\end{array}$ & the Degree of development of the economy \\
\hline \multicolumn{2}{|r|}{ Hebrew Kingdom } \\
\hline $\begin{array}{l}\text { The peak of religious } \\
\text { sentiment - the Psalms of } \\
\text { David, the Parables of } \\
\text { Solomon }\end{array}$ & $\begin{array}{l}\text { the richest state in its time - "was not richer than the king Solomon", } \\
\text { according to the Bible }\end{array}$ \\
\hline \multicolumn{2}{|r|}{$\underline{\text { Kievan Rus }}$} \\
\hline $\begin{array}{l}\text { Peaceful Christening of Rus } \\
\text { by Vladimir, deep Christian } \\
\text { Teachings of Yaroslav the } \\
\text { Wise and Vladimir } \\
\text { Monomakh, the Foundation } \\
\text { of the Kiev-Pechersk Lavra. } \\
\text { Pagan gods, Perun, } \\
\text { Dazhdbog, Veles were }\end{array}$ & $\begin{array}{l}\text { One of the most powerful national economies of Europe of 10-11 } \\
\text { centuries, the Adoption of Christianity gave a powerful boost to the } \\
\text { economy of the Slavic tribes. The Unification of the people always } \\
\text { leads to prosperity of its economy: every team that feels as one family, } \\
\text { works more, faster, and better. With the perception of Christianity very } \\
\text { active construction of churches started in the Russian cities, the first } \\
\text { monasteries appeared, the cult of the saints was established. The } \\
\text { monastery Republics as the largest economies gave work to entire }\end{array}$ \\
\hline
\end{tabular}


regional idols and the attempt of Prince Vladimir before the adoption of Christianity to establish the Slavic Pantheon of gods gave no result, - the worship of different deities led to the disunity of the Slavic world. Christianity was known and accepted, especially by Kiev, even before the baptism of Vladimir, but other tribes, for example, the Novgorods, remained pagans. The Christening of all Russia, which was held in the capital, Kiev, quite quickly, contributed to uniting numerous tribes into one state that was the largest one in Europe. villages. Russian monasteries gradually move from the cities to the countryside, usually virgin lands, develop the most inaccessible and wild places, small villages and later cities appear around deserted monasteries. The construction of an Orthodox Church, which always had exceptional splendor, required a large number of different skilled workmen, and Prince Vladimir invites the Greek artisans who teach their art to the Russians. Craftwork flourishes rapidly. The custom of regular fairs held at the walls of monasteries or on the square in front of the Church is established. The cult of saints and the veneration of icons attracts to urban and rural monasteries and famous temples many pilgrims, whose funds contribute to the prosperity of the churches and surrounding farms. Christian ascetics who work permanently serve as a role model for people.

Implanting of Christianity on Russian soil allowed the Slavs to learn the most developed culture of the 10th century - Byzantine. Christianity brought the written culture and education: the princes Vladimir and Yaroslav organise workshops for clerks, taking away children from the wealthiest citizens, and giving them to Church schools for training. Introduction to a variety of literature and various sciences dramatically broadens the mind of the Russians, thereby increasing their needs. The increasing demand for new and foreign goods and publications stimulates the development of crafts and trade.

Orthodox Christianity established the ban on such negative economic phenomenon as usury. The prosperity of the economy is based on the development of real economy: agriculture, beekeeping, hunting, fishing, handicraft as work of independent owners.

With the Baptism of Rus a special Slavic economic tradition was formed, in which economic objectives are subject of religious purposes, where the help to others is considered more important than enrichment (Sylvester), and where trading travel is more to get knowledge than to get profits (Afanasy Nikitin).

\section{$\underline{\text { India }}$}

Akbar the Great, a fusion of Muslim and Hindu traditions - double religious
One of the most powerful economies of the East: the establishment of trade relations even with distant Europeans (Portuguese and Italians); the construction of roads across the country with free spots for relaxation; strict tax accounting, eliminating public funds stealing; granting loans to the poor and not collecting taxes in case of bad harvest; public investment and giving land for Muslim, Hindu and Christian churches; the best Asian army that uses elephants, cannons and muskets

\section{$\underline{\text { China }}$}

The era of Han, 2nd century BC -2 century ad, the introduction of Confucianism in all spheres of life.
Powerful spurt of economy due to the unification of the country: the creation of the great Wall of China, the establishment of trade relations with Rome, the treasuries of wealthy merchants reach the level of the state Treasury, state support of the poor: giving them land, tools, money, accommodation, reduction of the land tax rate from $1 / 15$ to $1 / 100$ part. 


\begin{tabular}{|c|c|}
\hline \multicolumn{2}{|r|}{ Ancient Egypt } \\
\hline $\begin{array}{l}\text { The grand construction of the } \\
\text { religious monuments at } \\
\text { Ramses II: the giants of } \\
\text { Memphis, Luxor and Per- } \\
\text { Ramesses, the colossal } \\
\text { Hypostyle hall of Karnak } \\
\text { temple, one of the biggest } \\
\text { buildings of antiquity and the } \\
\text { modern world, with an area of } \\
5000 \text { sq. m. }\end{array}$ & $\begin{array}{l}\text { The Greatest dawn of the economy in Egypt: one of the first peace } \\
\text { treaties in history, signed between the Hittites and the Egyptians; the } \\
\text { "explosion" in trading activity in Asia and Egypt; the creation of large } \\
\text { prosperous cities; the prosperity of various temple crafts; reliable } \\
\text { architectural structures, most of which are still preserved to our time. }\end{array}$ \\
\hline \multicolumn{2}{|r|}{ The Modern Vatican } \\
\hline $\begin{array}{l}\text { Controls up to } 1 \text { billion of the } \\
\text { world's population } \\
\text { (Catholics). The worldwide } \\
\text { famous St. Peter's Cathedral } \\
\text { with its interior, the Vatican } \\
\text { museums, including the } \\
\text { Sistine chapel and the famous } \\
\text { Vatican library are situated in } \\
\text { the Vatican. }\end{array}$ & $\begin{array}{l}\text { The highest income per capita - up to } \$ 190,450 \text { a year. The income of } \\
\text { the Vatican Bank is up to } \$ 2 \text { trillion. As for the area }(0,44 \mathrm{~km} 2 \text {, the } \\
\text { length of the state border }-3,2 \mathrm{~km}) \text { and the population (up to } 880 \\
\text { people) it is the smallest state economy in the world. }\end{array}$ \\
\hline
\end{tabular}

Sources: compiled by the author based on data from the Statistical database of the UN [Electronic resource] - Mode of access: http://w3.unece.org/PXWeb/ru/Orthodoxy [Electronic resource] - Mode of access: http://Православие.Ru Illustrated history of religions. - SpasoPreobrazhensky Valaam monastery, 1992. - 900 S., Vernadsky G. V. the Golden age of Kievan Rus / G. V. Vernadsky. - M.: Algoritm, 2012. - 400 C., Flavius Joseph. Jewish war. - Minsk: Belarus, 1991. - 514 p., India [Electronic resource] - Mode of access: www.indostan.ru/Индия/44_769_0.html, Korotayev A. V. Long-term political-demographic dynamics of Egypt: Cycles and trends / A. V. Korotayev. - Moscow: Oriental literature, $2006-$ 200 p., Breasted, D., Turaev B. History of Ancient Egypt / D. Breasted, B. Turaev. - Mn.: Kharvest, 2003., K. Vasilyev. The origins of Chinese civilization / K. V. Vasiliev. - M., 1998. 200 S., SIMA Qian. Historical notes. In 9 vols. / SIMA Qian. - M.: Nauka (Main editorial Board for Eastern literature) - Eastern literature, 1972-2010., The CIA [Electronic resource] - Mode of access: https://www.cia.gov/open/.

\section{CONCLUSIONS}

Sociological methods helped to receive a confirmation of the theory of long waves and a formula of long wave which was also proved by statistics and historical facts. The results which were revealed in the course of quite considerable research should be taken into account by statesmen in creating and realization of macro-economic policy of the state as well as by businessmen in market micro-economic policy of firms: influencing the main economic subjects only with economical methods of stimulation or compulsion (by tax payments, fines and facilities, credits, licenses) is very narrow and not far-seeing, it means to suppose that a person doesn 't differ from speechless creatures, perfectly trained regularly by "the stick and the carrot" policy. 
People even in their economic behavior are led not only by motives of gaining but above all are guided by a model of moral-religious behavior which has existed in the nation for centuries, and also by their cultural interests and political sympathies, by their plans of advancing up the social ladder, as well as public opinion, or by the fashion which has been formed in the world.

\section{REFERENCES}

[1]. Kitaev Yu. A. (2017) The Role of small and medium-sized enterprises in the development of the "green" economy // "Green" economy: problems, state and prospects". Materials of the panel discussion. Belgorod, October 6, 2017 / Belgorod state agrarian University named after V. Ya. Gorin. - Belgorod: publishing house of the Belgorod state agrarian University, 104 p. - P. 29-32.

[2]. Kapinos R.V.(2014). The Future of humanity. Religious economy as the future of the world economy. Saarbrücken, Deutschland: LLAP, $501 \mathrm{p}$.

[3]. Kapinos R. V. (2015). The Future of the world economy. Kharkov: KNPU named after G. S. Skovoroda, $253 \mathrm{p}$.

[4]. Kapinos R. V.(2006). Monastic economy: economic relations and a place in the modern national economy. Moscow: Russian Academy of Sciences, Institute of Economics, centre for political and economic studies, 140c.

[5]. Kapinos R. V. (2014). Characteristic features of confessional economy // Vestnik BGTU im. V. G. Shukhov. No. 2, pp. 47-52.

[6]. Kapinos R. V.(2014). Characteristic features of effective confessional economy // Economics and entrepreneurship, № 4 (part 1), p.80-86.

[7]. Marx K.(1962). Das Kapital. Band I. Kritik der politischen Ökonomie. Karl Marx Friedrich Engels. Werke, Band 23, S. 11-802, Dietz Verlag, Berlin/DDR

[8]. Sombart, Werner (1911). Die Juden und das Wirtschaftsleben. Leipzig: Duncker.

[9]. Sombart, Werner (1913). Der Bourgeois. München und Leipzig: Duncker \& Humblot, 1913.

[10]. Sombart, Werner (1913). Krieg und Kapitalismus. München und Leipzig: Duncker \& Humblot, 1913.

[11]. Sombart, Werner (1913). Luxus und Kapitalismus. München: Duncker \& Humblot, 1922.

[12]. Sombart W. (1912).The Jews and economic life. - SP(b).: Publishing Of "Mind", p.214

[13]. Sombart W. Bourgeois(2004). Sketches on the history of the spiritual development of modern economic man; Jews and economic life. - M.: Iris-press, p.500

[14]. Sombart W.(2005). Selected works. - M.: territory of the future,p. 400

[15]. Schumpeter, J. A.. Chapter 1. Karl Marx (1818-1883) // Ten great economists from Marx to Keynes. - Moscow: Gaidar Institute, 2011. - S. 17-116. - 400 p.

[16]. Tugan-Baranovsky M. I. (1903). Essay VIII. Critics of the capitalist system (the end). Marx // essays on the recent history of political economy (Smith, Malthus, Ricardo, Sismondi, historical school, the katheder socialists, the Austrian school, Owen, Saint-Simon, Fourier, Proudhon, Rodbertus, Marx). — SPb.: Journal "the World of God", p.292-434.,p. 434

[17]. Weber M. Gesammelte Aufsatze zur Religionssoziologie 1920-1921.

[18]. Weber M.(1990). Selected works. - M.: Progress, p. 450

[19]. Weber M.(1994). Favorites. The Image of society. - M.: Yurist, p.300

[20]. Weber, M.(2006). The Protestant ethic and the spirit of capitalism. - Moscow: Russian political encyclopedia, p.200

[21]. Weber, M. (2010). Fundamentals of the theory of transport systems: tutorial. - SPb.: Saint Petersburg state University of architecture and civil engineering SPbGASU, p.214

[22]. Xenophon (1993).Socratic works. - SPb.: JSC "Komplekt», p.416

[23]. Zadorozhniy V. G. (2012).Human saving function of Economics. - Kharkiv,p.180 


\section{Article history:}

- Received 30 July 2018

- Accepted 5 December 2018 